\title{
LENKA PTAK
}

Uniwersytet Wrocławski, Polska

\section{Neologizmy z formantem obcym -ing we współczesnym języku czeskim}

Przedmiotem niniejszego artykułu są występujące w języku czeskim proste rzeczownikowe derywaty słowotwórcze utworzone od wspólnych podstaw zapożyczonych za pomocą różnych formantów sufiksalnych: -ing i -(ová)ní, -ing i -ství, -ing i -ace, -ing i -ismus/-izmus, -ing i -iště.

W opisie derywatów posługujemy się metodologią opartą na zasadach synchronicznego opisu słowotwórczego wypracowanego w językoznawstwie słowiańskim, przede wszystkim polskim i czeskim. Przeprowadzona analiza materiału będzie podstawą klasyfikacji słowotwórczo-semantycznej derywatów, charakterystyki podstaw ze względu na ich klasę gramatyczną oraz opisu funkcji pełnionych przez formanty. Zapożyczone leksemy nie zostały poddane szczegółowej analizie. Na przykładzie zebranego materiału zamierzamy bowiem wskazać na zjawisko synonimii słowotwórczej wśród neologizmów rzeczownikowych.

Wyraźnym znakiem nasilenia się procesów internacjonalizacji we współczesnych językach słowiańskich jest zauważalna w nich żywotność obcych środków słowotwórczych. Jest oczywiste, że zapożyczenia, które zyskały motywację słowotwórczą w języku biorcy, powiększają pulę jego derywatów słowotwórczych. Niektóre z nich przyczyniają się do powstania nowych typów słowotwórczych, inne do wzmożenia produktywności konkurujących z nimi środków rodzimych.

W języku czeskim produktywność zdobywają rzadkie wcześniej sufiksy pochodzenia obcego, typu -ing. Sufiks -ing w języku angielskim stosuje się w tworzeniu imiesłowu przysłówkowego współczesnego, imiesłowu przymiotnikowego czynnego oraz rzeczowników odczasownikowych, które łączą w sobie właściwości nominalne i werbalne (wyróżniają czas i rodzaj, zachowują reakcje werbalne i mogą być modyfikowane przez przysłówki). W języku będącym przedmiotem analizy zapożyczenia zakończone na -ing najczęściej przybierają znaczenie rzeczowników odczasownikowych, określają nazwy czynności, choć mogą też określać stan, środek albo miejsce czynności, niekiedy przybierają for- 
mę przymiotnikową, np. billing - billing informace, casting - casting direktor, revolving - revolving vklad, shopping - shopping centrum.

Liczebność rzeczowników zakończonych na -ing ciągle wzrasta, jednak jak słusznie zauważyła Halina Mieczkowska w monografii Zapożyczenia a paralele słowotwórczo-leksykalne $w$ rozwoju leksyki przełomu wieków (w ujęciu stowacko-polskim) - status sufiksu -ing nie jest we wszystkich leksemach jednakowy. Autorka wyróżnia następujące sposoby jego adaptacji w języku słowackim i polskim:

1. najczęściej sufiks ten został przejęty wraz z zapożyczeniem, którego stanowi część składową, np. słc. baby-sitting, catering, dišpecing, dresing/dressing, faktoring, fixing; pol. konsulting/consulting, kontroling/controling, holding, roaming;

2. wykorzystywany jest także do tworzenia słownictwa na gruncie rodzimym (często poprzez łączenie z leksemami pochodzenia obcego, chociaż w większym lub mniejszym stopniu zadomowionymi), przeważnie stylistycznie nacechowanego slangowością albo potocznością, niekiedy traktowanego jako okazjonalizmy, np. słc. raketing, šoking; pol. browaring, szoking, kloszarding, tajming;

3. sufiks ten łączy się również z podstawami rodzimymi, np. słc. dribling, forčeking, jachting, ležing; pol. łomżing, kraking, kocing, smażing, trawing, które często konkurują z nazwami w pełni rodzimymi, np. słc. jachtárstvo ${ }^{1}$.

Badaczka zwraca uwagę, że

niekiedy trudno jest jednoznacznie wskazać, czy dany leksem z sufiksem -ing należy uznać za derywat powstały na gruncie języka macierzystego, jak np. słc.: džoging/jogging, lobing/lobbing, manažering/managering, ekomonitoring, snoubording/snowboarding, sponzoring, surfing; pol.: banking, jogging, lobbing, menedżering/menadżering, monitoring, snowboarding, sponsoring, czy za gotową pożyczkę, por. słc.: kasting/casting, dresing/dressing, kliring/clearing, roaming, multitasking; pol.: kasting/casting, dressing, ranking, roaming, skejtbording/skateboarding ${ }^{2}$.

Krystyna Waszakowa, analizując neologizmy z -ing z bogatego zbioru 110 rzeczowników zakończonych tym sufiksem, za derywaty słowotwórcze o motywacji rzeczownikowej uznaje tylko 16 wyrazów: menedżering/menadzering 'zarządzanie przedsiębiorstwem lub jego częścią; pełnienie funkcji menedżera', snowboarding 'jeżdżenie na snowboardzie', rapping 'wykonywanie muzyki w stylu rap', banking 'formy zdobywania klientów banków poprzez proponowanie coraz to nowych ofert', canyoning/kanioning 'wspinanie się przez wiele godzin, spadanie z kilkunastu metrów do wody pod wodospadem, pokonywanie pontonem górskich rzek w wąskich, stromych wąwozach (kanionach)', clubbing/ klubing 'nocne odwiedzanie klubów; przemieszczanie się z klubu do klubu, zabawa w klubach', narkoting 'impreza klubowa, której uczestnicy zażywają narkotyki', bussing 'rozwożenie dzieci do szkoły busikiem', kloszarding ‘życie na

${ }^{1}$ Przykłady podaję za: H. Mieczkowska, Zapożyczenia a paralele słowotwórczo-leksykalne w rozwoju leksyki przełomu wieków (w ujęciu słowacko-polskim), Kraków 2015, s. 180.

2 Ibidem, s. 181. 
wzór kloszardów', lecz także lobbing, monitoring, sponsoring i spaming, które wykazują związek nie tylko z rzeczownikiem, ale też utworzonym od niego na gruncie polszczyzny czasownikiem ${ }^{3}$.

Podstawę materiałową naszych badań nad językiem czeskim stanowią przede wszystkim słowniki Akademický slovník cizích slov (dalej: ASCS), Nová slova věeštině (dalej: NSČ 1) oraz Nová slova v češtině 2 (dalej: NSČ 2), który nawiązuje do tomu 1 zarówno pod względem chronologicznym, jak i treściowym. Słownik Nová slova v češtině odnotowuje neologizmy powstałe w latach 1985-1995, podczas gdy Nová slova v češtině 2 zawiera ok. 7000 haseł z lat 1996-2002. Chociaż słowniki neologizmów w odróżnieniu od słowników normatywnych nie odnotowują słownictwa standaryzowanego, ustabilizowanego, odzwierciedlają tendencje, które uwidaczniają się w obecnym języku czeskim zarówno w ortografii, jak i na poziomie fonetycznym czy morfologicznym. Z tego powodu słownik neologizmów może mieć duże znaczenie przy stabilizacji normy językowej. Wyodrębnienie bowiem takich jednostek, jak neologizmy wiąże się z ich nieustabilizowaniem językowym, a ściślej mówiąc — z niezarejestrowaniem w słownikach objaśniających. Kolejnym etapem rozwoju neologizmów jest albo ich stabilizacja, czyli włączenie do zbioru najnowszego słownictwa, albo zupełne wyjście z obiegu językowego. Zebrane w dwu tomach słownika Nová slova v češtině neologizmy pochodzą przede wszystkim z prasy (gazet oraz czasopism), źródeł internetowych, programów telewizyjnych oraz literatury popularnej ${ }^{4}$.

W zebranym materiale (NSČ 1, NSČ 2) odnotowano 117 rzeczowników utworzonych od podstaw zapożyczonych, zakończonych na -ing, np.: biking, briefing, casting, catering, dressing, feeling, jogging, jumping, managering, managing, modeling, strečink, styling, timing. Niektóre wyrazy posiadają wariant $\mathrm{z}$-ink, który jest wynikiem graficznej adaptacji leksemu na podstawie wymowy, kiedy dochodzi do zatarcia (neutralizacji) opozycji fonem dźwięczny/bezdźwięczny w wygłosie, np. brifink, dabink, floatink, jachtink, koučink, manažerink, manažink, skautink, skrečink ${ }^{5}$.

W materiale wyekscerpowanym ze słowników NSČ 1, NSČ 2 odnotowano współpodstawowe nazwy czynności utworzone za pomocą formantów -ing i -(ová)ní, -ing i -ství, ing i-ace, -ing oraz-ismus/-izmus, -ing i -iště. Nazwy czynności z sufiksem -ing przejmowane są z języka angielskiego najczęściej również $\mathrm{z}$ wyrazami powiązanymi z nimi formalnie i znaczeniowo, np. sponzor, sponzoring. Od rzeczowników tych tworzone są czasowniki z formantem -ovat, np.

${ }^{3}$ K. Waszakowa, Przejawy internacjonalizacji w słowotwórstwie wspótczesnej polszczyzny, Warszawa 2005, s. 116-117.

${ }^{4}$ Nová slova v češtině, red. O. Martincová, Praha 1998 (dalej: NSČ 1), s. 535-556; Nová slova $v$ češtině 2, red. O. Martincová, Praha 2004 (dalej: NSČ 2), s. 563-568.

${ }^{5} \mathrm{O}$ graficznej adaptacji i poprawności ortograficznej zapożyczeń zakończonych na -ing/-ink w języku czeskim zob. D. Svobodová, K otázce spisovnosti vybraných typů přejatých lexikálních jednotek, [w:] Sborník př́spěvků z konference s mezinárodní účastí. Čěstina-jazyk slovanský 3, red. R. Šink, Ostrava 2009, s. 138-152. 
sponzor > sponzorovat, przez które już na gruncie języka czeskiego motywują się zapożyczone leksemy z -ing oraz tworzone równolegle do nich nazwy czynności $\mathrm{z}$ formantem -(ová)ní, np. sponzorovat > sponzoring, sponzorování. Waszakowa owo wchodzenie obcych formantów na gruncie języka polskiego w relacje synonimiczne $\mathrm{z}$ odpowiednimi formantami rodzimymi interpretuje jako swoiste „ścieranie się” tendencji do internacjonalizacji i tendencji „narodowej”, wyrażającej się w preferowaniu środków rodzimych ${ }^{6}$. O konkurencji między rodzimymi i obcymi formantami wśród neologizmów piszą badacze języka czeskiego i słowackiego ${ }^{7}$.

Łatwość tworzenia derywatów z rodzimymi formantami od podstaw obcych Danuta Buttler uznała za jedną z uderzających cech powojennego słowotwórstwa. Badaczka zauważyła, że rzeczowniki zapożyczone ze względu na potrzeby czysto składniowe - konieczność użycia w zdaniu przymiotnika relacyjnego czy czasownika - uzyskują rodzimą „obudowę słowotwórczą”, zanim jeszcze ustabilizuje się ich pisownia czy fleksja. Buttler zauważyła, że do polszczyzny regularnie włączane są całe rodziny wyrazów obcych, czego wyrazem jest powstawanie „modeli grupowych”, obejmujących pożyczki wraz z całą serią utworzonych od nich wyrazów pochodnych ${ }^{8}$.

Wyrazy zakończone na -ing i -(ová)ní wykazują pełną synonimiczność semantyczną i stylistyczną. Ze słowników NSČ 1 oraz NSČ 2 wyekscerpowano 25 par takich wyrazów: koučink/coaching - koučování/coachování, cracking crackování, dealing — dealováni, hackering — hackování, hosting — hostování, jogging - joggování, lobbing - lobování, mobbing — mobbování, modeling - modelování, monitoring - monitorování, morfing - morfování, rafting raftování, sampling — samplování, scanning — scanováni/skenování, scouting/ skauting — scoutování/skautování, scratching — skrečování, scrolling — skrolo-

${ }^{6}$ K. Waszakowa, op. cit., s. 181, 204.

${ }^{7} \mathrm{Na}$ konkurencyjność, a zwłaszcza na stopień synonimiczności derywatów utworzonych za pomocą sufiksów obcych i rodzimych w języku słowackim zwraca uwagę Klára Buzássyová w artykułach Konkurencia slovotvorných typov s formantmi -izácia, -ovanie oraz Konkurencia slovotvorných typov s formantmi -ita, -ost'. Autorka, opierając się na materiale językowym i analizie struktur semantycznych, dzieli analizowane derywaty na konkretne grupy rzeczowników odczasownikowych pod względem synonimiczności. W języku słowackim konkurencja między formantami rodzimymi i obcymi uwidacznia się w derywatach utworzonych od tych samych podstaw z sufiksami -izácia - -ovanie, -ita - -ost', -izmus - -stvo. Zob. eadem, Konkurencia slovotvorných typov s formantmi -izácia, -ovanie, „Slovenská reč” 1983, nr 48, s. 268-277; eadem, Konkurencia slovotvorných typov s formantmi -ita, -ost', „Slovenská reč” 1986, nr 51, s. 142-152. Zob. też J. Mravinacová, Přejímání cizích lexémi̊, [w:] Neologizmy v dnešní češtině, red. O. Martincová, Praha 2005, s. 207-209; O. Martincová, Konkurence prefixálních komponenti̊ v novém lexiku, „Slovo” 1997, nr 4, s. 124-139; eadem, Na okraj konkurence slovotvorných prostředkü (U př́ležitosti životního jubilea M. Dokulila), „Slovo a slovesnost” 1997, nr 58, s. 161-164.

${ }^{8}$ D. Buttler, Tendencje rozwojowe w zasobie słownym powojennej polszczyzny, [w:] Wspótczesna polszczyzna. Wybór zagadnień, red. H. Kurkowska, Warszawa 1981, s. 208. 
vání, spamming — spamování, sponzoring — sponzorování, surfing — surfování, taping — tejpování, tuneling — tunelování, vaxing — vaxování, zapping — zapování, zorbing — zorbování.

Synonimię wśród wymienionych leksemów możemy w zwięzły sposób zilustrować następującymi przykładami wybranymi z materiału słownikowego uzupełnionego o przykłady tekstowe (Český národní korpus SYN 2015).

1.jogging - joggování:

— jogging sport. 'běhání pro zdraví, rekreační běh; jogging dělá doslova zázraky; udržovat si kondici joggingem' (NSČ 1);

- joggováni sport. 'běhání pro zdraví, rekreační běh; jogging: tradiční ranní Clintonovo joggování' (NSČ 1);

Por. np. konteksty: při joggingu $v$ hotelových fitness centrech se ted' dival na hudebni kanály oraz léta joggováni po matčině boku Eureku naučily, jak takové „špatné" počasí dokáže dodat obyčejnému běhu kouzlo.

2. monitoring - monitorování:

- monitoring '1. sledování něčeho pomocí monitorovacího zařízení; monitorování (ve významu 1): monitoring oxidu siřičitého v Praze; automatický monitoring ovzduší 2. soustavné sledování, pozorování, kontrolování něčeho; monitorování (ve významu 2): monitoring tisku; celosvětový monitoring životního prostředí; globální monitoring komunikace mezi bankami 3. instituce nebo skupina lidí, která má na starosti monitorování: v monitoringu BBC pracuje mnoho lidí' (NSČ 1);

- monitorování '1. sledování něčeho pomocí monitorovacího zařízení; monitoring (ve významu 1): monitorování ovzduší, monitorování škodlivých látek, monitorování životního prostředí, monitorování epidemiologické situace; monitorování letadel; monitorování v medicíně 2. soustavné sledování, pozorování, kontrolování něčeho za nějakým účelem; monitoring (ve významu 2): monitorování tisku; monitorování projevů rasizmu; monitorování protřeb zdravotnictví; monitorování dlouhodobých projektů' (NSČ 1).

Nieregularnym zjawiskiem jest tworzenie nazw czynności z sufiksami -ing/-ink i -ství. Wyekscerpowaliśmy 7 par takich wyrazów: gambling - gamblerství, hacking - hakerství, jachting - jachtařství, manažerink - manažerství, sponzoring - sponzorství/sponzorování, squatting — squatterství, tuneling - tunelovániltunelářství.

1. jachting - jachtařství:

- jachting '[-ty-], jachtink, -u m. (6. j. -u) sport. provádění jachetního sportu: příručka j-u a plachtění' (SSJČ);

- jachtařství 'dyscyplina sportowa' (Český národní korpus SYN verze 6).

2. sponzoring - sponzorstvi/sponzorování:

— sponzoring 'poskytování finanční či věcné podpory pro nějakou činnost; sponzorování: sponzoring obstaraly zahraniční firmy (...)’ (NSČ 1);

- sponzorství 'poskytování finanční či věcné podpory pro nějakou činnost sponzora (ve významu 1); sponzoring, sponzorování (...)’ (NSČ 1); 
- sponzorování 'poskytování finanční či věcné podpory pro nějakou činnost; sponzoring: sponzorování fotbalového týmu (...)’ (NSČ 1).

Nieregularnym zjawiskiem jest również synonimia wśród wyrazów zakończonych na -ing i -ace oraz -ing i -ismus/-izmus (lobbing - lobbismus/lobbizmus - lobováni). Tworzenie nazw czynności z dwoma obcymi wykładnikami -ing i -ismus/-izmus jest rzadkim zjawiskiem. Formant -ace w języku czeskim wykorzystywany jest $\mathrm{w}$ tworzeniu rzeczowników nazywających czynności oraz rezultaty czynności. Nowe formacje często wchodzą w relacje synonimiczne z rzeczownikami odczasownikowymi zakończonymi na -(ová)ní, a więc one również będą tworzyć pary synonimiczne $\mathrm{z}$-ing, $\mathrm{np}$. floating - floatace, tuneling - tunelaceltunelování.

Jaký je zájem o floating mezi vaši klientelou? | Různorodý. Nelze ani hovořit o průměrných číslech za týden, měsíc. Každé dva měsíce se snažime dosud nedoceněné klady floatace přibližovat veřejnosti rüznou formou, za pomoci sdèlovacich prostředků. Přesto dva roky, co floating provozujeme, stále není ziskový. Některý den přijde sedm zájemci̊, dalši den čtyři nebo nikdo. Př́ zavedeni floatingu... [Neomat $]^{9}$

Derywaty nienacechowane procesualnością, posiadające znaczenie rezultatywne, w których nastąpiła zmiana znaczenia abstrakcyjnego na znaczenie konkretne, oznaczają stan, środek albo miejsce czynności. Ich charakter rzeczownikowy przejawia się w tym, że mogą występować także w liczbie mnogiej. Nieliczne wchodzą w konkurencję sufiksalną, np.: -ing i -iště (np. parking - parkoviště). O zachowaniu tożsamości semantycznej derywatów parking — parkoviště świadczy wykorzystanie w tekstach zamiennie obu sufiksów:

Ani hlídaná parkoviště nejsou zárukou proti poškození nebo dokonce vykradeni auta. Výjimku netvoři ani parking obchodního domu Kotva. („Večerník Praha” 4.11.1994, s. 3)

Adaptacja zapożyczeń przyczynia się nie tylko do wzbogacenia systemu słowotwórczego języka czeskiego o nowe elementy genetycznie obce (podstawy oraz wykładniki słowotwórcze), lecz także wpływa na aktywność istniejących środków słowotwórczych (rodzimych i obcych). Mieczkowska, analizując leksemy z cząstką -ing w języku słowackim i polskim, słusznie zauważa, że większość leksemów z ową cząstką to leksemy przejęte z języka angielskiego, a więc niemotywowane na gruncie słowiańskim, którym nie można przypisać pochodności słowotwórczej, ale można wyznaczyć rolę podstaw słowotwórczych w tworzeniu dalszych derywatów ${ }^{10}$.

Poniżej przedstawiamy przykłady zapożyczeń występujących w roli podstaw derywatów przymiotnikowych (jak i utworzonych od nich przysłówków), wyekscerpowanych ze słowników NSČ 1, NSČ 2, ASCS, SSČ, SSJČ, np.: casting $\rightarrow c a-$ stingový, clearing $\rightarrow$ clearingový (ale też klíring $\rightarrow$ klíringový), feeling $\rightarrow$ feelingový, gambling $\rightarrow$ gamblingový, happening $\rightarrow$ happeningový, koučink/coaching

${ }^{9}$ Databáze excerpčního materiálu Neomat, verze 3.0, Praha 2015, http://neologismy.cz/.

${ }^{10}$ H. Mieczkowska, op. cit., s. 181. 
$\rightarrow$ koučinkový/coachingový, lobbing $\rightarrow$ lobbingový, mastering $\rightarrow$ masteringový, paging $\rightarrow$ pagingový, sponzoring $\rightarrow$ sponzoringový, strečing $\rightarrow$ strečingový (ale też strečink $\rightarrow$ sterčinkový), dumping/damping $\rightarrow$ dumpingový/dampingový $\rightarrow$ dumpingověldampingově.

Zarysowana analiza synonimii sufiksalnej podkreśla wysoki stopień aktywności derywacji sufiksalnej. Przedstawione zapożyczenia wtapiają się w system leksyki rodzimej, przyczyniając się do wzrostu aktywności słowotwórczej podsystemu rodzimego. Utrzymywanie się produktywności przyrostka -ing może wynikać z ciągłego zapotrzebowania na skondensowane struktury o funkcji nominatywnej.

Na zakończenie należy zauważyć, że obserwowana w zbiorze neologizmów synonimia może z jednej strony wskazywać na konkurencję wśród sufiksów, z drugiej zaś świadczyć o nieustabilizowaniu formacji typu -ing w języku czeskim.

\section{Bibliografia}

\section{Źródła}

ASCS - Akademický slovník cizích slov, red. V. Petráčková, J. Kraus, Praha 2001.

NSČ 1 - Nová slova v češtině, red. O. Martincová, Praha 1998.

NSČ 2 - Nová slova v češtině 2, red. O. Martincová, Praha 2004.

SSČ -Slovník spisovné češtiny pro školu a veřejnost, red. J. Filipec et al., Praha 2004.

SSJČ - Slovník spisovného jazyka českého, t. 1-4, Praha 1960-1971.

\section{Literatura}

Buttler D., Tendencje rozwojowe w zasobie słownym powojennej polszczyzny, [w:] Współczesna polszczyzna. Wybór zagadnień, red. H. Kurkowska, Warszawa 1981.

Buzássyová K., Konkurencia slovotvorných typov s formantmi -izácia, -ovanie, „Slovenská reč” 1983, $\mathrm{nr} 48$.

Buzássyová K., Konkurencia slovotvorných typov s formantmi -ita, -ost', „Slovenská reč” 1986, nr 51.

Jadacka H., System stowotwórczy polszczyzny (1945-2000), Warszawa 2001.

Martincová O., Konkurence prefixálních komponentů v novém lexiku, „Slovo” 1997, nr 4.

Martincová O., Na okraj konkurence slovotvorných prostředků (U př́ležitosti životního jubilea M. Dokulila), „Slovo a slovesnost” 1997, nr 58.

Mieczkowska H., Zapożyczenia a paralele słowotwórczo-leksykalne w rozwoju leksyki przełomu wieków (w ujęciu słowacko-polskim), Kraków 2015.

Svobodová D., Internacionalizace současné české slovní zásoby, Ostrava 2007.

Svobodová D., K otázce spisovnosti vybraných typů přejatých lexikálních jednotek, [w:] Sborník přispěvků z konference s mezinárodní účastí Čeština - jazyk slovanský 3, red. R. Šink, Ostrava 2009.

Waszakowa K., Przejawy internacjonalizacji w słowotwórstwie współczesnej polszczyzny, Warszawa 2005. 


\section{Loanwords with -ing formation in the Czech language}

\section{Summary}

The text deals with problem of the new lexical borrowings used in the Czech language. We concentrate on neologisms, which are of great importance for rise and development of concurrence. Certain types of concurrence based upon suffixal process applied at the formation of new words are analyzed. The paper presents and examines -ing formations used in Czech language (dabing // dabování, jogging // joggování, lobbing // lobbování).

Keywords: linguistics, word formation, loan-words, suffixes, nouns.

\section{Přejatá substantiva na -ing v současné češtině}

Obsah

$\mathrm{V}$ př́íspěvku jsme se zaměřili na anglicismy s příponou -ing (adaptovanou $\mathrm{v}$ češtině v podobě -ink), které jsou do češtiny přejímané v původních gerundiálních či participiálních tvarech. Soustřed'ujeme se na tvoření domácích potějšků přejímek na -ing. Substantiva slovesná zakončená na -(ová)ni se hojně v současné době odvozují od sloves vzniklých z cizích základů a tvoří tak největší počet domácích protějšků přejímek na -ing. Vznikají tak dvojice synonym jako dabing // dabování, jogging // joggování, lobbing // lobbování.

Kličová slova: jazykověda, tvoření slov, přjímky, sufixy, nominativa. 